\title{
Postcolonial Ballads
}

\section{Labels}

I have many names

first and last

in English and in Spanish

the difference is minute

but I hear it.

My name in English

does not sound like my name

it sounds foreign

does not sound

as my mother calls me

my name in Spanish

sounds like family

my close friends say it this way.

I have names of what I am

or what I have been

in response to those seeking to file me

in a neat compartment

of memory

or highlight

some perceived inadequacy.

I'm Chilean

Canadian

Ecuadorian

Sociologist

Teacher.

I'm a short

fair skinned

dark haired

immigrant

without an accent.

I'm a woman

open

curious

explorer of ideas

animal lover

survivor. 
I'm a "gringa" Latina

temperamental

yet patient.

I'm a spirit seeker

experience weaver

artist and writer

poet and painter

chaos and beauty maker.

I'm political

analytical

unorthodox

and law abiding.

I am often not

what I appear to be

and yet I am

an open book.

I am

much more than adjectives or nouns.

I am

a complete imperfect being

as is everyone I face

so why limit

experience

with labels

that disable

on a face? 